\title{
The impact of COVID-19 in the state of Mississippi
}

\author{
Chidinma A. Chikere*, Rasaki Aranmolate ${ }^{* *}$, Ogbonna Eugene Chikere*** \\ * Public Health department, The University of Southern Mississippi \\ ${ }^{* * *}$ Public Health department, Jackson State University \\ Orthopedics and Trauma department, Federal Medical Center, Abeokuta \\ DOI: 10.29322/IJSRP.10.09.2020.p10593 \\ http://dx.doi.org/10.29322/IJSRP.10.09.2020.p10593
}

\begin{abstract}
Since the outbreak of Coronavirus disease (COVID19 ) in late 2019, it has become a global pandemic, with severe impact on health and economy. The increasing prevalence of COVID-19 cases and the deaths in the United States (US) indicates a lack of compliance with the national and state guidelines by the Centers for Disease Control and Prevention (CDC). Mississippi (MS) has one of the highest number of cases and deaths than the national U.S average. This study reveals the risks and burden of COVID-19 in MS when compared to the US national average and proposes strict preventive measures to reduce the spread of Covid-19 in the state of Mississippi. This could be achieved through social distancing, use of face coverings, proper hand hygiene, virtual learning, decentralized contact tracing, and a probable second lockdown.
\end{abstract}

Index Terms- COVID-19, SARS-CoV-2, Pandemic, Infection, Mississippi.

\section{INTRODUCTION}

$\mathrm{C}$ OVID-19 is an infectious disease that is caused by the newly discovered Coronavirus: Severe Acute Respiratory Syndrome Coronavirus 2 (SARS-CoV-2) [1]. The COVID-19 outbreak first started in 2019, in Wuhan, China and has since become a global pandemic [1]. Individuals could become directly infected through respiratory droplets between person-to-person and indirectly through contaminated hard surfaces [2]. The symptoms of COVID-19 include weakness, cough, fever or chills, myalgia, new loss of taste or smell, nausea or vomiting, difficulty breathing, headache, diarrhea, sore throat, and runny nose [3]. Although these symptoms may appear 2-14 days after an individual is exposed to the virus, it is worth noting that some cases present without showing any symptoms [3], [4].

COVID-19 affects people of all ages [5]. However, the severity of illness increases with age and the presence of underlying conditions such as type 2 diabetes mellitus (T2DM), obesity, cancer, sickle cell disease, asthma, severe heart conditions, chronic obstructive pulmonary diseases (COPD), and chronic kidney diseases [5], [6]. While children rarely suffer from complications of COVID-19, a 90\% increase in cases involving children has been reported by the American Academy of Pediatrics [7]. Conversely, adults experience COVID-19-related complications such as cerebrovascular accident, acute respiratory Distress Syndrome, pulmonary embolism, myocardial infarctions, cardiac arrest, and death [8]-[10]. The CDC guidelines on the Covid-19 prevention and control measures include frequent hand hygiene, wearing a mask when around other people, keeping six feet distance from others, cleaning and disinfecting surfaces, and most importantly isolating in the presence of symptoms or exposure to SARS-CoV-2 [2], [11].

In the United States (US), the social inequities that have historically affected individuals from ethnic and racial minority groups have contributed to increased risks of becoming infected with COVID-19 among members of these groups [12]. The CDC data revealed that when compared with whites, black people were 2.1 times more likely to die from COVID-19, followed by indigenous people (1.4 times), and Latinos (1.1 times) [13]. Similarly, data from COVID Racial Data Tracker revealed that death caused by COVID-19 is higher in black people (81 per $100,000)$ than in Hispanic or Latino (46 per 100,000), American Indian or Alaska Native (44 per 100,000), White people (32 per 100,000), and Native Hawaiian and Pacific Islander (32 per 100,000) [14].

Mississippi (MS) has continued to report high number of new cases which poses a public health problem especially as it relates to its population and available resource [13]. The state's initial response to COVID-19 was a shelter-in-place order that required closing all schools and non-essential businesses [15]. Eventually, reopening plans such as sanitation guidelines, statewide mandatory face covering, strict social distancing, and limiting in-door gathering to ten people were set in place [15]. Despite having a reopening plan, the state continues to record high number of new cases and deaths after resumption which could be a resultant effect of non-compliance with CDC guidelines [13]. In spite of the urgent need for prompt healthcare actions, the Mississippi State Department of Health (MSDH) and the government still face challenges such as inadequate number of contact tracers, lack of funding, time lags between testing and result, and incomplete contact information of tested individuals [16]. With a state population of 2,976,149 and a total of 904 Intensive Care Unit (ICU) beds in the entire state, shortage of bed could be imminent if cases continue to rise [17], [18]. Experts have estimated a loss of $\$ 7.9$ trillion and $\$ 6.6$ billion on the US and MS economy, respectively [18], [19]. The 
purpose of this paper was to elucidate the number of cases and death rates associated with Covid-19 in all the counties in Mississippi

\section{MISSISSIPPI COVID-19 DATA}

Over a period of three months, the MSDH has reported 70,665 new COVID-19 cases and 1,615 deaths bringing the total number of cases and death to 71,755 and 2,080, respectively [21]. To understand the burden of the increasing cases and deaths in MS, it is important to compare Covid-19 cases and death rates among the US and MS population. The ratio of new cases associated with Covid-19 between US and MS was 85:1 [13], [21]. It means that for every 85 new cases in the US there is 1 new case in MS [13], [21]. Additionally, the total number of cases in MS was 2,124 per 100,000 population while US reported 1,465 per 100,000 population [13]. This reveals higher rates of COVID-19 infection in MS when compared to the US and emphasizes the increased risks and burden in MS.

Importantly, the number of MS COVID-19 cases among Blacks are higher when compared to Whites [21]. The MSDH record showed that out of the total number of COVID-19 cases, $53.0 \%$ were non-Hispanic Black, 38.5\% were Non-Hispanic Whites, $5.2 \%$ were Hispanics, $1.8 \%$ were others, $1.1 \%$ were NonHispanic American Indian or Alaska native, and $0.4 \%$ were Asians [21]. Similarly, out of all the COVID-19 related deaths $50.8 \%$ were non-Hispanic Blacks, $43.2 \%$ were non-Hispanic whites, $3.7 \%$ were Non-Hispanic American or Alaska Native, $1.6 \%$ were Hispanics, and $0.6 \%$ were others [21]. Gender has been found to influence the disease distribution as females $(57.1 \%)$ were at higher risk of becoming infected than males $(42.4 \%)$ and unknown $(0.5 \%)$ [21].

The high rate of COVID-19 and poorer outcomes among racial and ethnic minorities occur as a result of disparity in access to social determinants of health such as quality education, health care services, good job opportunities, safe housing, and healthy foods [22], [23]. Racial and ethnic minority groups are more likely to be uninsured, live in overcrowded houses, and work in a high risk Covid-19 environment than non-Hispanic whites [22], [24], [25].

Table 1. COVID-19 Cases and Deaths by County level in Mississippi [21].

\begin{tabular}{ccc}
\hline County & Total Cases & Total Deaths \\
\hline \hline Hinds & 5878 & 128 \\
De Soto & 3888 & 34 \\
Harrison & 2755 & 37 \\
Madison & 2538 & 74 \\
Jackson & 2449 & 47 \\
Rankin & 2411 & 41 \\
Jones & 1978 & 64 \\
Forrest & 1905 & 57
\end{tabular}

\begin{tabular}{|c|c|c|}
\hline Washington & 1811 & 46 \\
\hline Lee & 1700 & 43 \\
\hline Lauderdale & 1488 & 98 \\
\hline Neshoba & 1328 & 96 \\
\hline Lamar & 1284 & 19 \\
\hline Bolivar & 1219 & 40 \\
\hline Warren & 1173 & 37 \\
\hline Oktibbeha & 1171 & 41 \\
\hline Panola & 1139 & 18 \\
\hline Lowndes & 1136 & 42 \\
\hline Sunflower & 1106 & 29 \\
\hline Lafayette & 1062 & 21 \\
\hline Scott & 1029 & 21 \\
\hline Copiah & 986 & 30 \\
\hline Pike & 977 & 38 \\
\hline Leflore & 976 & 70 \\
\hline Holmes & 945 & 50 \\
\hline Yazoo & 887 & 14 \\
\hline Pontotoc & 884 & 9 \\
\hline Lincoln & 871 & 44 \\
\hline Monroe & 868 & 55 \\
\hline Grenada & 866 & 27 \\
\hline Simpson & 852 & 36 \\
\hline Coahoma & 812 & 13 \\
\hline Leake & 811 & 27 \\
\hline Wayne & 808 & 21 \\
\hline Tate & 768 & 30 \\
\hline Marshall & 766 & 10 \\
\hline Union & 761 & 19 \\
\hline Marion & 707 & 21 \\
\hline Adams & 664 & 28 \\
\hline Covington & 656 & 16 \\
\hline Winston & 652 & 18 \\
\hline George & 637 & 9 \\
\hline Pearl River & 596 & 41 \\
\hline Newton & 587 & 12 \\
\hline Tallahatchie & 565 & 11 \\
\hline Attala & 549 & 25 \\
\hline Walthall & 525 & 22 \\
\hline Chickasaw & 508 & 19 \\
\hline Prentiss & 497 & 11 \\
\hline Noxubee & 482 & 12 \\
\hline Tishomingo & 467 & 12 \\
\hline Alcorn & 451 & 5 \\
\hline Tippah & 434 & 14 \\
\hline Calhoun & 433 & 9 \\
\hline Jasper & 424 & 11 \\
\hline
\end{tabular}




\begin{tabular}{|c|c|c|}
\hline Hancock & 422 & 15 \\
\hline Itawamba & 422 & 10 \\
\hline Smith & 421 & 13 \\
\hline Clay & 417 & 14 \\
\hline Claiborne & 414 & 14 \\
\hline Tunica & 375 & 8 \\
\hline Clarke & 368 & 28 \\
\hline Montgomery & 365 & 10 \\
\hline Lawrence & 341 & 8 \\
\hline Yalobusha & 324 & 10 \\
\hline Humphreys & 310 & 12 \\
\hline Quitman & 278 & 1 \\
\hline Greene & 275 & 13 \\
\hline Carroll & 265 & 11 \\
\hline Webster & 257 & 13 \\
\hline Perry & 256 & 8 \\
\hline $\begin{array}{c}\text { Jefferson } \\
\text { Davis }\end{array}$ & 253 & 6 \\
\hline Stone & 249 & 6 \\
\hline Kemper & 248 & 14 \\
\hline Amite & 246 & 6 \\
\hline Wilkinson & 233 & 14 \\
\hline Sharkey & 215 & 7 \\
\hline Jefferson & 198 & 8 \\
\hline Benton & 165 & 1 \\
\hline Franklin & 150 & 2 \\
\hline Choctaw & 141 & 4 \\
\hline Issaquena & 27 & 2 \\
\hline Total & 71,755 & 2,080 \\
\hline
\end{tabular}

Table 1 shows the number of COVID-19 cases and deaths by county level, with Hinds recording the highest number (cases, 5878 vs deaths, 128), Issaquena has the lowest number of cases (cases, 27 vs death, 2) and Benton (cases, 165 vs deaths, 1) [21]. Hinds (5878 cases) is followed by De Soto (3888), Harrison (2755), Madison (2538), Jackson (2449), Rankin (2411), Jones (1978), Forrest (1905), Washington (1811), Lee (1700), Lauderdale (1488), Neshoba (1328), Bolivar (1219), Warren (1173), Oktibbeha (1171), Panola(1139), Lowndes(1136), Sunflower (1106), Lafayette (1062), and Scott (1029) [21]. In contrast, counties like Copiah, Pike, Leflore, Holmes, Yazoo, Pontotoc, Lincoln, Monroe, Grenada, Simpson, Coahoma, Leake, Wayne, Tate, Marshall, Union, Marion, Adams, Covington, Winston, George, Pearl River, Newton, Tallahatchie, Attala, Walthall, Chickasaw, Prentiss, Noxubee, Tishomingo, Alcorn, Tippah, Calhoun, Jasper, Hancock, Itawamba, Smith, Clay, Claiborne, Tunica, Clarke, Montgomery, Lawrence, Yalobusha, Humphreys, Quitman, Greene, Carroll, Webster, Perry, Jefferson Davis, Stone, Kemper, Amite, Wilkinson, Sharkey, Jefferson, Benton, Franklin, Choctaw, and Issaquena have recorded less than 1000 cases each [21]. Counties that have recorded 50 deaths and above include Hinds (128), Lauderdale (98), Neshoba (96), Madison (74), Leflore (70), Jones (64), Forrest (57), Monroe (55), and Holmes (50) [21]. Taking prompt public health actions in all these counties could lead to significant reduction in the spread and death associated with SARS-CoV-2.

\section{DISCUSSION}

In just three months, MS has recorded over 100\% increase in new COVID-19 cases which escalated from 1,090 to 71,755 [21], [26]. This could be partly due to the high prevalence of chronic diseases (diabetes mellitus, cancer, lung diseases) among racial and ethnic minority groups [27]. According to CDC, people with hypertension, obesity (BMI $\geq 30$ ), or diabetes were three times more likely to become hospitalized if they became infected with SARS-CoV-2 [28]. Similarly, people with asthma (1.5 times), chronic kidney disease ( 4 times), and severe obesity (BMI $\geq 40$ [4.5 times]) experience higher COVID-19 related hospitalization than people without these conditions [28]. Besides, poor social determinants of health (low income, unhealthy lifestyle, substandard education) can contribute to the prevalence of COVID-19 among racial and ethnic minority groups [22]. With the high number of COVID-19 cases in MS, hospitalization into ICUs and Medical/surgical units have steadily increased leaving only $17 \%$ of ICU beds and $30 \%$ of Medical/Surgical unit beds available [18]. Despite the State Health Officer's warning on the likelihood of hospitals going beyond capacity, some people continue to ignore the public health guidelines (face covering, social distancing, hand hygiene) [29]. This strongly suggests that the healthcare system will soon experience an overwhelming increase in COVID-19 cases which could aggravate the existing burden of this virus on the state [29].

\section{CONCLUSION}

In order to minimize severe outcome of COVID-19, the existing guidelines for prevention and control such as proper hand hygiene, mandatory face covering, social distancing, safe public gathering, and plans for reopening of schools and businesses should be maintained [30]. Since COVID-19 pandemic is an emerging situation, strict implementation of measures based on new findings could be beneficial in reducing the spread of SARS-CoV-2. More importantly, MS should consider using California's approach to education by making all classes virtual [31]. Furthermore, as some states such as California have already done, contact tracing should be decentralized to involve both the local and state health departments and possibly contract it out to a privately-owned company [32]. Lastly, more stringent measures such as statewide lockdown should be enforced until there is a significant reduction in number of cases [29].

COVID-19 cases will reduce if there is increased compliance with the CDC's guidelines on prevention and control of SARSCoV-2. Face coverings and social distancing should be maintained while virtual learning and strict contact tracing 
should be implemented. Strict actions may be more efficient in reducing the spread of SARS-CoV-2.

\section{ACKNOWLEDGMENT}

\section{Nneka Rogers, Jamie Hamil}

\section{REFERENCES}

[1] World Health Organization. "Q\&A on coronaviruses (COVID-19)." https://www.who.int/emergencies/diseases/novel-coronavirus2019/question-andanswers-hub/q-a-detail/q-a-coronaviruses. (accessed August 15, 2020).

[2] Centers for Disease Control and Prevention. "How Covid-19 spreads." https://www.cdc.gov/coronavirus/2019-ncov/prevent-gettingsick/how-covid-spreads.html (Accessed August 15, 2020).

[3] Centers for Disease Control and Prevention. "Symptoms of Covid19." https://www.cdc.gov/coronavirus/2019-ncov/symptomstesting/symptoms.html (accessed August 12, 2020).

[4] Centers for Disease Control and Prevention. "About masks." https://www.cdc.gov/coronavirus/2019-ncov/prevent-gettingsick/about-face-coverings.html (accessed August 12, 2020).

[5] Centers for Disease Control and Prevention. "Older Adults." https://www.cdc.gov/coronavirus/2019-ncov/need-extraprecautions/older-adults.html (accessed August 12, 2020).

[6] Centers for Disease Control and prevention. "People with certain medical conditions." https://www.cdc.gov/coronavirus/2019ncov/need-extra-precautions/people-with-medicalconditions.html?CDC_AA_refVal=https\%3A\%2F\%2Fwww.cdc.gov $\% 2$ Fcoronavirus \%2F2019-ncov\%2Fneed-extraprecautions\%2Fgroups-at-higher-risk.html (accessed August 20, 2020).

[7] American Academy of Pediatrics. "Children and COVID-19: Statelevel data report." https://services.aap.org/en/pages/2019-novelcoronavirus-covid-19-infections/children-and-covid-19-state-leveldata-report/ (accessed August 15, 2020).

[8] A. Sharifi-Razsavi, N. Karimi, and N. Rouhani, "Covid 19 and intracerebral hemorrhage: causative or coincidental," New Microbes New infect, vol. 35, pp. 1-2, May 2020, https://doi.org/10.1016/j.nmni.2020.100669

[9] The Lancet. "Mortality and pulmonary complications in patients undergoing surgery with perioperative SARS-CoV-2 infection: an international cohort study." 396(10243), pp. 27-38, May 2020, https://doi.org/10.1016/S0140-6736(20)31182-X

[10] American College of Cardiology. "COVID-19 clinical guidance for the cardiovascular care team." ACC Clinical Bulletin. https://www.acc.org/ /media/665AFA1E710B4B3293138D14BE8D1 213.pdf (accessed August 6, 2020).

[11] Centers for Disease Control and Prevention. "What to do if you are sick." https://www.cdc.gov/coronavirus/2019-ncov/if-you-aresick/steps-when-sick.html (accessed August 3, 2020).

[12] Centers for Disease Control and Prevention. "Health equity considerations \& racial ethnic minority groups." https://www.cdc.gov/coronavirus/2019-ncov/community/healthequity/race-ethnicity.html\#fn10 (accessed August 3, 2020).

[13] Centers for Disease Control and Prevention. "United States COVID19 cases and death by states." https://www.cdc.gov/covid-datatracker/index.html\#cases (August 14, 2020).
The COVID Tracking Project. "The COVID racial data tracker." https://covidtracking.com/race (accessed August 20, 2020).

This publication is licensed under Creative Commons Attribution CC BY. http://dx.doi.org/10.29322/IJSRP.10.09.2020.p10593
Office of Governor Tate Reeves. "Coronavirus (COVID-19) Update \& Resources." https://governorreeves.ms.gov/covid19/\#executiveOrders (accessed August 20, 2020).

E. Hensley, \& K. D. Betz. What Oxford's missing COVID-19 cases tell us about contact tracing in Mississippi. https://mississippitoday.org/2020/07/12/the-trouble-with-contacttracing-in-mississippi// (accessed July 30, 2020).

United States Census Bureau. "QuickFacts Mississippi; Unites States."

https://www.census.gov/quickfacts/fact/table/MS,US/PST045219 (accessed July 30, 2020).

Mississippi State Department of Health. "COVID-19 Hospital capacity and usage reports."

https://www.msdh.ms.gov/msdhsite/_static/resources/10040.pdf (accessed August 14, 2020).

S. Ziv. "Coronavirus Pandemic will cost U.S. economy $\$ 8$ trillion." Personal finance.

https://www.forbes.com/sites/shaharziv/2020/06/02/coronaviruspandemic-will-cost-us-economy-8-trillion/\#3c592f3515e4 (accessed August 20, 2020).

L. Ramseth. "Deeply disturbing: Coronavirus impact on Mississippi’s economy." Mississippi Clarion Ledger.

https://www.clarionledger.com/story/news/politics/2020/03/20/corona virus-impact-mississippi-economy/2865088001/ (accessed July 30, 2020).

Mississippi State Department of Health. "Coronavirus disease 2019 (COVID-19)."

https://www.msdh.ms.gov/msdhsite/_static/14,0,420.html (accessed August 15, 2020).

Centers for Disease Control and Prevention. "Health Equity Considerations \& Racial \& ethnic minority groups." https://www.cdc.gov/coronavirus/2019-ncov/community/healthequity/race-ethnicity.html (accessed August 15, 2020).

Office of Disease Prevention and Health Promotion. "Social determinants of health." Healthy people.

https://www.healthypeople.gov/2020/topics-objectives/topic/socialdeterminants-of-health (accessed August 20, 2020)

E. R. Berchick, J. C. Barnett, \& R. D. Upton. "Current Population Reports, P60-267(RV), Health Insurance Coverage in the United States: 2018" U.S. Government Printing Office, Washington, DC, 2019. (accessed August 20, 2020)

Economic Policy Institute. "Black workers face two of the most lethal preexisting conditions for coronavirus-racism and economic inequality." 2020 [cited 2020 Jun 28].

https://www.epi.org/publication/black-workers-covid/external icon (accessed August 14, 2020)

Facebook.com. "Mississippi State Department of Health." https://www.facebook.com/HealthyMS/photos (accessed August 14, 2020).

J. Davis, J. Penha, O. Mbowe, D. A. Taira. "Prevalence of single and multiple leading causes of death by race/ethnicity among people aged 60 to 70 years." Public Health Research, Practice, and Policy. 2017. Volume 14. http://dx.doi.org/10.5888/pcd14.160241

Centers for Disease Control and Prevention. "Hospitalization related to underlying medical conditions." 
https://www.cdc.gov/coronavirus/2019-ncov/coviddata/investigations-discovery/hospitalization-underlying-medicalconditions.html (accessed August 25, 2020).

[29] A. Lee. “'Major disaster' looms as Mississippians ignore COVID-19 rules, top health officials says."

https://www.sunherald.com/news/coronavirus/article243758402.html (accessed August 20, 2020)

[30] Mississippi State Department of Health. "COVID-19 Guidance and Prevention for individuals and the community." https://www.msdh.ms.gov/msdhsite/_static/14,21866,420.html\#EO15 07 (accessed August 25, 2020).

[31] G. Birenbaum and J. Bikales. "Here's your state's plan for reopening school." The Hill. https://thehill.com/homenews/state-watch/508105heres-your-states-plan-for-reopening-schools (accessed August 15, 2020).

[32] National Academy for State Health Policy. "State Approaches to contact tracing during the Covid-19 pandemic."

https://www.nashp.org/state-approaches-to-contact-tracing-covid-19/ (accessed August 15, 2020).

\section{AUTHORS}

First Author - Chidinma A. Chikere, MPH, The University of Southern Mississippi, Hattiesburg, MS, USA, chidinma.chikere@usm.edu

Second Author - Rasaki Aranmolate, MPH, PHD, Jackson State University, Jackson, MS, USA, ayodeji88@yahoo.co.uk

Third Author - Ogbonna Eugene Chikere, Medical Officer, Federal Medical Center, Abeokuta, Ogun, Nigeria, chikereeugene@gmail.com

Corresponding Author - Chidinma A. Chikere, chidinma.chikere@usm.edu, 6014472340 